\title{
Pozbawiony tytułu esej o państwie, które odwróciło się od własnych dzieci
}

\author{
$\underline{\text { ANDRZEJ PITRUS }}$
}

Polecieliśmy do Chin jesienią 2007 r., jeszcze przed olimpiadą w Pekinie i przed trzęsieniem ziemi w prowincji Syczuan, które dokonało ogromnych zniszczeń i zabrało życie niemal siedemdziesięciu tysiącom ludzi. Już wtedy czuło się zmianę ustrojową, choć niekoniecznie była to zmiana dobra - w rozumieniu: „na lepsze". Zamiast milionów rowerów na ulicach pojawiły się luksusowe samochody. Pekin stał się jednym z najbardziej zakorkowanych i zanieczyszczonych miast na świecie - sami Chińczycy żartowali wtedy, że teraz nawet po gazetę nie chodzi się pieszo. Kiedy reżim pozwolił obywatelom się bogacić, zaczęto się obnosić z posiadanymi dobrami materialnymi. Bywało, że kosztowne mercedesy parkowano przed blokowiskami, w których na trzydziestu metrach kwadratowych mieszkało dwanaście osób. Samochód był najważniejszy, podobnie jak nieco wcześniej w Polsce, Bułgarii czy Rumunii. Nadal nie było mowy o demokracji. Chińczycy postanowili wybrać trzecią drogę: nie wolność, ale wolny (przynajmniej w pewnym zakresie) rynek.

Oczywiście największymi beneficjentami zmiany były elity władzy. Zwykłym obywatelom żyło się nieco lepiej, a kiedy indziej jeszcze gorzej, bo uwolnienie gospodarki zawsze pociąga za sobą uwidocznienie się różnic społecznych i ekonomicznych. W stolicy wybudowano piękny dworzec kolejowy, przed którym na posłaniach z gazet i tektury po plazmowych telewizorach koczowali przybysze z prowincji. Stać ich było na bilet $\mathrm{w}$ jedną stronę, a wielu nie znalazło w Pekinie pracy. Nie tylko duma nie pozwalała im wrócić w rodzinne strony; wielu po prostu nie miało za co. Oprócz dworca wizytówką miasta miał się stać stadion nazywany ptasim gniazdem. Autorem koncepcji był Ai Wei Wei - dzisiaj jeden z najbardziej znanych chińskich artystów i dysydentów. Wtedy wiele osób zastanawiało się, dlaczego zdecydował się wziąć udział w tworzeniu propagandowego widowiska, jakim była olimpiada $\mathrm{w}$ sierpniu 2008 r. Odpowiadał, że artysta powinien tworzyć, a jego pociągała możliwość zaprojektowania architektonicznej struktury tak wielkich rozmiarów. Później zapewne żałował, oskarżając zresztą innych twórców zaangażowanych w olimpijski projekt o kolaborację z reżimem. Ceremonię otwarcia igrzysk miał tworzyć Zhang Yimou wspierany przez Stevena Spielberga. Ten ostatni wycofał się w proteście przeciwko łamaniu praw człowieka w Chinach. Zhang Yimou - wybitny reżyser, niegdyś krytykujący chińską dyktaturę, a dziś pozwalający jej drapać się za uszami - został sam, by stworzyć najbardziej spektakularny i najdroższy w historii spektakl multimedialny: piękny, zapierający dech w piersiach, ale i na swój sposób przerażający. 
Azja fascynuje mnie od dawna, ale nadal jestem daleki od jej zrozumienia - mimo podróży, obejrzanych filmów, licznych tekstów, które im poświęciłem. Nawet mimo głębokich i mądrych książek Alicji Helman o twórcach tak zwanej piątej generacji (sam zaraziłem ją fascynacją Orientem, ale teraz to ja mogę się od niej uczyć).

Niedawno powróciłem na Daleki Wschód, ale tym razem nie do ChRL, ale do Wietnamu - fascynującego kraju, gdzie podają najlepsze na świecie jedzenie i wprost boską kawę - który od niedawna podąża chińską ścieżką. Również tam reżim ma się dobrze, ale rynek stopniowo się uwalnia. Spotkałem tam wielu obcokrajowców - w tym Polaków - którzy „wybrali wolność” w Hanoi czy Sajgonie. Podróżowałem po Wietnamie przez dwa tygodnie jako członek polskiej delegacji filmowej, w ramach nawiązywania współpracy między naszymi kinematografiami. W przeddzień wylotu do Polski trafiliśmy do Hoi An, pięknego miasteczka w okolicach Da Nang, położonego nad rzeką, prawie jak Kazimierz nad Wisłą. Zabraliśmy grupę naszych „aniołków” - tak nazywaliśmy asystentów, którymi byli świetnie mówiący po angielsku studenci lokalnego uniwersytetu. Było nam dobrze i wesoło. Podczas obiadu w „knajpce z wejściem przez klozet” ${ }^{~}$ zażartowałem, że powinni szybko przenieść na papier zdjęcia ze swoich smartfonów, by móc zdobyć autografy naszej delegacji. Nie myślałem o sobie. Raczej o filmowcach:

- Patrzcie! Jest z nami Agata Trzebuchowska. Grała w filmie, który dostat Oscara.

- Ooooo! Oscar - wykrzyknęli młodzi ludzie chórem.

- No i Allan Starski. Też dostat Oscara, i to za film nakręcony ze Stevenem Spielbergiem!

-Ooooo! Oscar... A Steven Spielberg to kto? - zapytał jeden z „aniołków”.

Pozostali też nie wiedzieli. Allan nie potrafił ukryć zdumienia, ja także, ale po chwili uświadomiłem sobie, że przecież jesteśmy w Wietnamie, gdzie zachodnia kultura popularna stanowi margines. Oczy młodych ludzi patrzą tam przede wszystkim w stronę Japonii, a zwłaszcza Korei. To jest ich „,wielki świat”. Hollywoodzkie produkcje są dla nich egzotyką, co w naszych postkolonialnych rozumkach nie zawsze się mieści.

Azja jest inna i świat przekonał się o tym boleśnie przy okazji trzęsienia ziemi w Syczuanie, do którego doszło w najmniej odpowiednim dla chińskich władz terminie - na kilka miesięcy przed propagandowym sportowym widowiskiem mającym przekonać świat, że Chiny są państwem nowoczesnym, dynamicznym i otwartym na świat. Choć kataklizmy wywołane przez siły natury wydają się czymś, co nie powinno naruszać wspomnianego wizerunku, katastrofa ta sprawiła, że chiński reżim „stracił twarz”. Pojęcie guanxi ${ }^{2}$ może być trudne do zrozumienia dla człowieka wywodzącego się z kultury zachodniej, ale dla Chińczyka jest fundamentalne. Wypadnięcie z roli, przeszacowanie swojego lub cudzego miejsca w hierarchii, czy nawet niezależne od nas wydarzenia zakłócające spójność wizerunku są czymś, co dla obywatela Państwa Środka jest katastrofą.

Jeszcze raz wracam wspomnieniami do naszej podróży z 2007 r. Byliśmy wtedy między innymi w niezwykle malowniczym mieście Yangshuo. Główną atrakcją był tam dla nas plenerowy spektakl Zhanga Yimou, o którym Alicja pisała wtedy książkę. Scenę ustawiono na wodzie na pobliskim jeziorze, a wystąpiło na niej ponad tysiąc wykonawców - więcej niż było widzów, choć oczywiście wszystkie bilety sprzedano. Rozgrzewka przed Pekinem. Przedostatniego dnia spotkaliśmy tam lokalną rzeź- 
biarkę, która zgodziła się wykonać dla nas piękną kamienną pieczęć-ekslibris z naszymi imionami po polsku i zapisanymi chińskimi znakami. Kiedy przyniosła swoje dzieło, powiedziała do mnie: Mam nadzieję, że będzie dobrze stużyć tobie i twojej mamie. Wtedy różnica wieku była chyba dużo bardziej widoczna. Dziś Alicja odmłodniała, a ja posiwiałem. Niestety - czego żałuję do dzisiaj - sprostowałem błąd, a artystka z Yangshuo „straciła twarz”. Na nic były tłumaczenia, że podobny „,afront”, który raczej nas bawił, niż frustrował, zdarzał się nam nader często.

To niewiarygodne, ale chińskie władze początkowo celowo zaniżały dane dotyczące kataklizmu, właśnie w obawie przed utratą twarzy. W wypadku trzęsień ziemi o sile większej niż 8 stopni w skali Richtera do akcji rusza pomoc międzynarodowa. Reżim nie chciał jej jednak przyjąć właśnie w trosce o guanxi, a także w obawie o to, że nagłośnione zostaną nieprawidłowości, które doprowadziły do kataklizmu tak wielkich rozmiarów. W końcu jednak po tygodniu Chińczycy zwrócili się o pomoc międzynarodową, która przybierała różne formy. W akcji ratunkowej uczestniczyli specjaliści między innymi z Korei Południowej, Tajwanu i Singapuru. Z całego świata napływała pomoc rzeczowa i finansowa. W rezultacie nie udało się ukryć zaniedbań, które doprowadziły do katastrofy, choć wysiłki władz zmierzające do zmanipulowania medialnego wizerunku trzęsienia ziemi czasem okazywały się skuteczne ${ }^{3}$. Chodziło przede wszystkim o nieprawidłowości podczas budowy szkół, w których zginęły tysiące chińskich dzieci, choć w istocie nie musiało do tego dojść, gdyby budynki zostały wzniesione zgodnie z zasadami sztuki architektonicznej. Poza tym wskazywano na rabunkową gospodarkę prowadzoną $\mathrm{w}$ regionie będącym jednym z biedniejszych zakątków Chin. Być może do zakłócenia równowagi sejsmicznej przyczyniła się też budowa zapór wodnych ${ }^{4}$. O trzęsieniu pisali i Chińczycy, i autorzy zachodni. Pierwsi częściej wypowiadali się w tonie umiarkowanym (na przykład Sonny Shiu-Hing Lo w konkluzji swojej książki podkreśla, że chińskie władze po dramatycznych doświadczeniach w Syczuanie nauczyły się od Chile - gdzie dwa lata później miało miejsce równie silne trzęsienie ziemi, które jednak nie pochłonęło tylu ofiar z uwagi na inne standardy budowlane - jak w przyszłości pokonywać podobne kryzysy ${ }^{5}$ ), podczas gdy Christian P. Sorace zdemaskował ideologiczny przekaz chińskiej dyktatury ${ }^{6}$.

Dla mnie - z przyczyn oczywistych - najbardziej interesujące są reakcje artystów z kręgu sztuk wizualnych, nawiązujących do dramatycznych wydarzeń z maja 2008 r. Mimo że temat był wielce niewygodny dla chińskiego rządu, powstało całkiem sporo prac - skądinąd o bardzo zróżnicowanej specyfice. Najwięcej zrealizowano filmów - niektóre o raczej „użytkowym”, informacyjnym charakterze, ale także kilka pretendujących skutecznie do rangi utworów artystycznych. Znane są także instalacje Ai Wei Weia, który właśnie po trzęsieniu ziemi w Syczuanie stał się wrogiem numer jeden chińskiego reżimu. Jego działania z pogranicza sztuki i aktywizmu stały się na tyle niewygodne dla władz, że postanowiły one doprowadzić do uwięzienia artysty, który był przetrzymywany przez ponad osiemdziesiąt dni bez wyroku. Nałożono także na niego areszt domowy i nakazano zniszczenie wybudowanego dopiero co studia. Wszystko oczywiście pod pretekstem ,zbrodni” niemających nic wspólnego z działaniami Ai Wei Weia, prowadzącego prywatne śledztwo w sprawie trzęsienia ziemi. Legalnie postawiony budynek okazał się nieoczekiwanie samowolką zagrażającą bezpieczeństwu publicznemu, a artystę oskarżono o malwersacje finansowe i niepłacenie podatków. 
Ai Wei Wei poświęcił trzęsieniu ziemi dwa filmy wideo, w których skupił się na śmierci uczniów pogrzebanych pod gruzami tak zwanych tofu houses. Stalowe wzmocnienia niezbędne do stworzenia stabilnej konstrukcji były w nich zastępowane lichymi żelaznymi drutami, a wykorzystywany do wypełniania konstrukcji cement składał się głównie z piasku. W rezultacie szkoły rozsypywały się jak domki z kart, a trzęsienie zaczęło się krótko po godzinie 14.00, w salach lekcyjnych nadal byli uczniowie. Chiński artysta i działacz postanowił ustalić nazwiska tragicznie zmarłych dzieci i systematycznie publikował stale powiększającą się listę. Do 2 września 2008 r. udało mu się odkryć tożsamość 4851 ofiar. Dlatego jego wideo wyświetlane jako pętla nosi tytuł 4851 (2008). Realizacja ta ma bardzo minimalistyczny charakter - na czarnym ekranie są po prostu wyświetlane nazwiska dzieci zanotowane chińskim pismem. Efektem działań Ai Wei Weia był także inny utwór filmowy, Policzki małej dziewczynki (2008), będący dokumentem zmontowanym z materiałów nakręconych na terenie katastrofy. Twórca nie tylko przedstawił w nim obraz ogromu tragedii i zniszczeń, ale też dotarł do rodzin ofiar i ukazał pracę wolontariuszy, dzięki którym udało się stworzyć bazę danych rejestrującą tożsamość zabitych. Filmy prezentowane w galeriach podczas wystaw chińskiego artysty, dostępne również w serwisie YouTube, pokazują, jak umowna jest granica między aktywizmem i sztuką.

Nieco inny charakter mają instalacje zainspirowane wydarzeniami w Syczuanie. Pierwsza powstała już w 2009 r. i została wyeksponowana na fasadzie monachijskiego Haus der Kunst. Remembering to rodzaj ogromnego barwnego muralu wykonanego z tysięcy kolorowych plecaczków, powszechnie używanych przez chińskie dzieci do noszenia podręczników i przyborów szkolnych. Jak w wypadku wielu innych dzieł mistrza, mamy tu jednak do czynienia z czymś w rodzaju work in progress. W innych wariantach podobne instalacje pojawiły się jako części monograficznych wystaw - między innymi w Berlinie i Wiedniu.

Jeszcze bardziej intrygującym i poruszającym projektem był Straight. Jego przygotowanie trwało cztery lata (2008-2012), a pozornie minimalistyczny efekt można było obejrzeć między innymi podczas Biennale w Wenecji. Dzieło było eksponowane $\mathrm{w}$ pustym pomieszczeniu wypełnionym zardzewiałymi żelaznymi prętami. Mogło ono budzić skojarzenia z rodzajem ogrodu zen, w którym drobne kamienie zastąpiono kawałkami metalowych wzmocnień. Sens pracy ujawnia się jednak dopiero wtedy, gdy dowiadujemy się, czym one są w istocie. W komentarzu do pracy czytamy, że wszystkie pręty zostały znalezione na terenie trzęsienia ziemi i były elementami konstrukcyjnymi wspomnianych wcześniej tofu houses. Artysta wraz ze swoimi współpracownikami zachował je i wyprostował w symbolicznym geście mającym odwoływać się do pragnienia odwrócenia tragedii.

Bardzo częstym kontekstem dla artystycznych wypowiedzi na temat tragedii z 2008 r. jest kataklizm, który nawiedził Chiny ponad trzydzieści lat wcześniej. Wtedy dramat rozegrał się w innej części kraju - doszczętnie zniszczone zostało miasto Tangshan, liczące wówczas około miliona mieszkańców. W ciągu kilku minut z metropolii nie zostało prawie nic, a według oficjalnych danych - spotkałem się z opiniami, że są one znacznie zaniżone - zginęło ponad 240 tysięcy ludzi ${ }^{7}$. Chiny były wtedy inne - tragedia wydarzyła się bowiem pod sam koniec okresu rewolucji kulturalnej, na kilka miesięcy przed śmiercią Mao. Trzęsienie uderzyło 28 lipca, a chiński przywódcza zmarł 8 września, co doprowadziło do zwrotu politycznego, 
który jednak nie zmienił sytuacji w kraju ani w sposób skokowy, ani radykalny. Najbardziej mroczny okres historii najnowszej Chin miał jednak dobiec końca.

Skala tragedii była jeszcze większa niż w 2008 r., ale oczywiście można doszukiwać się analogii. W 1976 r. kraj był odcięty od reszty świata - wedle oficjalnej doktryny liczyło się tylko to, co chińskie, także oryginalne metody wykrywania nadciągających klęsk żywiołowych. Okazało się jednak, że sejsmolodzy nie byli W stanie przewidzieć tragedii lub - jak chcą niektórzy komentatorzy ${ }^{8}$ - władze nie ujawniły ich ustaleń. Gdyby mieszkańców ostrzeżono, byłaby szansa na choćby częściową ewakuację, a ponieważ pierwsza fala uderzyła przed czwartą rano, zdecydowana większość obywateli miast była w domach, które w mgnieniu oka stały się ich grobowcami.

Analogii między wydarzeniami z połowy lat 70. a tragedią w Syczuanie szuka przede wszystkim Wang Libo w dokumencie Pogrzebani (2009). Choć nie miał on szerokiej dystrybucji w kinie, został pokazany na festiwalu filmowym w Pekinie, na którym otrzymał nawet nagrodę. Praktyka znana od lat - wiele reżimów, także bliższych nam geograficznie, pozwalało na krytyczne wypowiedzi artystów, traktując je jako rodzaj przykrywki, niemającej w istocie zbyt wielkiej siły sprawczej w walce politycznej. Czy Carlos Saura mógł zagrozić Franco? Z pewnością nie.

Choć film skupia się przede wszystkim na tragedii Tangshan, reżyser wyraźnie daje do zrozumienia, że interesuje go mechanizm aktualny i wtedy, i dzisiaj. Mówi o tym nie tylko w filmie, ale i w komentarzu do niego ${ }^{9}$. Paradoksalnie, choć jego teza o zatajeniu informacji o zbliżającym się trzęsieniu ziemi jest dobrze uargumentowana wypowiedziami świadków, reżyser nie daje jasnej odpowiedzi, dlaczego władze dopuściły do tak wielkich tragedii. W wypadku Syczuanu odpowiedź jest prawdopodobnie prostsza - przyczyną była rabunkowa eksploatacja mniej znaczącego i ubogiego regionu kraju. Ale dlaczego poświęcono Tangshan? Miasto to było ważnym ośrodkiem przemysłowym, działały tam wielkie kopalnie węgla, które w wyniku kataklizmu zostały zalane wodą. Być może sprawna skądinąd akcja ratownicza miała być fundamentem kampanii propagandowej? Z punktu widzenia człowieka Zachodu jest to nieracjonalne i nielogiczne. Pamiętajmy jednak o guanxi.

Inne spojrzenie na tragedię w Syczuanie znajdziemy w dokumencie kreacyjnym 1428 (2009). Du Haibin nakręcił materiał do swojego filmu tuż po kataklizmie. Wydaje się, że mamy tu do czynienia $\mathrm{z}$ dokumentem obserwacyjnym zapisującym nie tylko skalę zniszczeń, ale też reakcje władz i samych poszkodowanych. Te ostatnie są czasem bardziej niż zaskakujące - obok pojedynczych narzekań na zbyt opieszałą pomoc pojawia się wiele wypowiedzi podkreślających sprawność działań Partii, a jeden z rozmówców reżysera cieszy się wręcz, że „dzięki” trzęsieniu ziemi będzie miał okazję zobaczyć znanego wcześniej tylko z telewizji polityka. Czy zatem Du Haibin zrobił film propagandowy? Zdecydowanie nie. Wydaje się raczej, że oprócz samej katastrofy interesował go specyficznie chiński rodzaj „zniewolenia umysłu”.

Wspomniałem o jedynie pozornie obserwacyjnym charakterze dokumentu. Określenie to nie odnosi się bynajmniej do manipulacji, jakiej miałby dopuścić się reżyser. Sceny dokumentalne nie pozostawiają raczej wątpliwości co do ich autentyczności. Wielu z nich nie dałoby się po prostu „ustawić”, a twórcy najczęściej nie mieli okazji kręcenia dubli, bo należało po prostu uchwycić to, co się działo w danym momencie. Du Haibin zdecydował się jednak na bardzo delikatne, ale i efektowne zaznaczenie, że mamy do czynienia z pewną opowieścią, rodzajem 


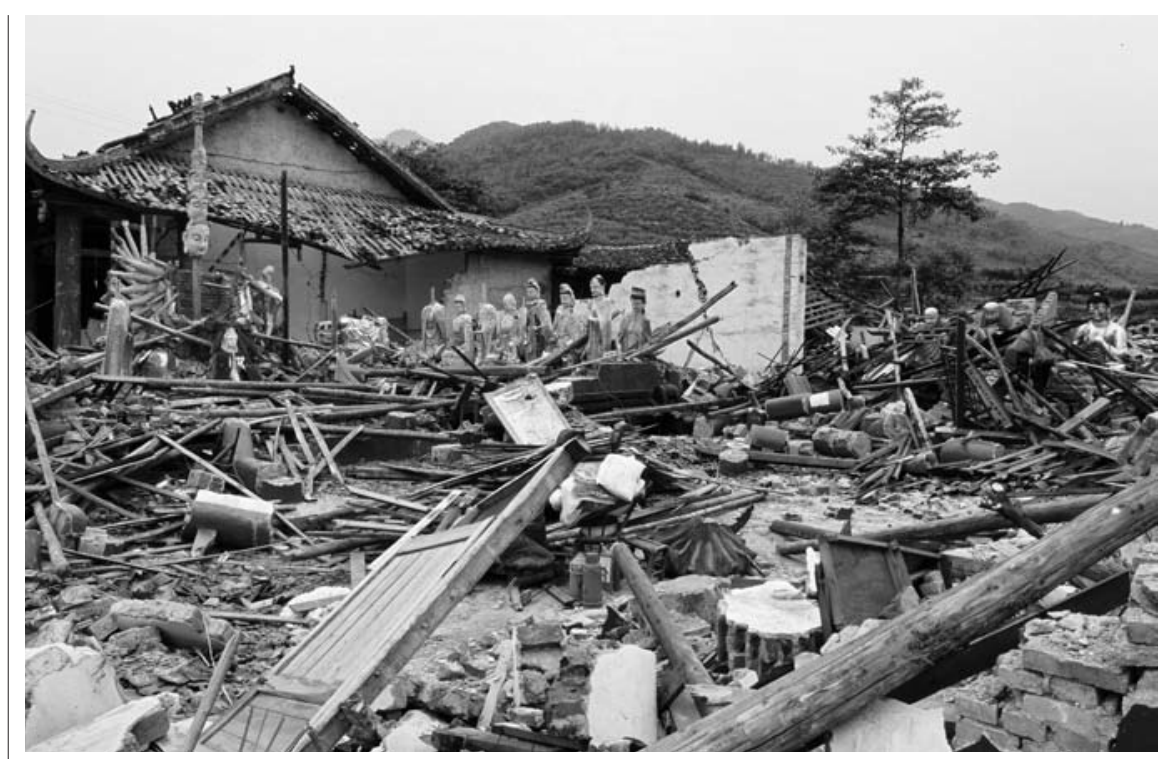

1428, reż. Haibin Du (2009)

fikcji rozegranej na materiale wziętym z rzeczywistości. Sygnałem do takiego właśnie rozpoznania świata przedstawionego filmu jest postać włóczęgi błąkającego się po terenach zniszczonych przez wstrząsy. To jedyny bohater, który został wyreżyserowany tak, jak ma to miejsce w filmie fabularnym. Nie gra go aktor, lecz bezimienny mężczyzna, który ocalał z katastrofy. Jego wędrówka może się kojarzyć z wyprawą do kolejnych kręgów piekieł - reżyser rejestruje bowiem także to, co nie mogłoby zostać pokazane w oficjalnych mediach: walkę o przetrwanie, nie zawsze fair, czasem na pograniczu utraty godności. $Z$ drugiej strony reżyser zdecydowanie ucieka przed uogólnieniem. Tytuł filmu, w którym została zaszyfrowana godzina rozpoczęcia trzęsienia ziemi w Syczuanie, przypomina, że o tragedii tysięcy ludzi można opowiedzieć wprost, a poszukiwanie metafory dla jej wyrażenia byłoby aktem niegodziwym.

W filmie jest tylko jeden zindywidualizowany bohater - wspomniany już włóczęga. Wprowadza on jednak perspektywę bliską tej, jaką odnajdziemy w pracach Ai Wei Weia. Obydwaj twórcy - niejako na przekór konfucjańskiej wizji świata poszukują w tej zbiorowej tragedii także dramatu jednostki, jakby chcieli nadać imiona anonimowym ofiarom, często zapomnianym przez władze.

Na koniec zupełnie inny głos na temat tragedii w Syczuanie. Film Fenga Xiaoganga, znany na Zachodzie jako Aftershock (2010), a w istocie zatytułowany po prostu Trzęsienie ziemi w Tangshan, jest jedyną realizacją wysokobudżetową spośród tu omówionych. Należy on, podobnie jak większość pozostałych prac reżysera, do kręgu tzw. kina nowego roku - nurtu powstałego pod koniec lat 90., który ma być chińską odpowiedzią na propozycje Hollywoodu. Podobnie jak Pogrzebani, film mówi przede wszystkim o wydarzeniach z 1976 r., ale przedstawia je w zupełnie inny sposób i w krańcowo odmiennym celu. Był chińskim kandydatem do Oscara (nominacji nie otrzymał), a jednocześnie największym przebojem ${ }^{10} \mathrm{~W}$ historii kina tego kraju. 
Trzęsienie ziemi $w$ Tangshan nie jest, w przeciwieństwie do realizacji niezależnych, krytyczne wobec władz. Wręcz przeciwnie - ten sprawnie zrealizowany melodramat rodzinny można postrzegać jako utwór propagandowy. Twórcy wrócili w nim do wydarzeń z 1976 r. po to, by szukać nie analogii, ale raczej możliwości przesunięcia uwagi i wykazania skuteczności działań mających na celu opanowanie kryzysu w Syczuanie. Argumentacja została przeprowadzona w mistrzowski sposób $\mathrm{z}$ wykorzystaniem formuły wenyi pian ${ }^{11}$ - specyficznie chińskiej ${ }^{12}$ melodramy, w której niekoniecznie występują klasyczne wątki miłosne. Natomiast zastosowanie afektywnej formuły sprawia, że widz jest poddawany dość bezwzględnemu szantażowi emocjonalnemu. Rozwiązania dramaturgiczne, postaci i dialogi podlegają tu daleko idącej konwencjonalizacji. Jednym z popularnych motywów wenyi pian jest rozdzielenie rodziny, po którym następuje cudowne spotkanie po latach. Ten właśnie trop został wpleciony przez Fenga Xiaoganga do opowieści o dwóch trzęsieniach ziemi. Twórca więcej uwagi poświęca pierwszemu - to wtedy poznajemy bohaterkę Li Yuanni, matkę dwojga dzieci, która najpierw traci męża, a później musi dokonać dramatycznego wyboru. Fang Deng i Fang Da zostają uwięzieni pod zwałami gruzów i przygnieceni przez ogromny betonowy blok. Ratownicy mogą podważyć go tylko $\mathrm{z}$ jednej strony, ale konsekwencją takiego działania musi być poświęcenie jednego z maluchów. Mając do wyboru uratowanie jednego dziecka lub utratę obojga, Yuanni wskazuje syna jako tego, który ma zostać ocalony. Oczywiście - zgodnie z zasadami wenyi pian - nie wie, że również dziewczynka przeżyła. Nie zdaje sobie sprawy także z tego, że słyszała ona matkę wydającą na nią „wyrok” śmierci.

Córka bohaterki trafia do rodziny zastępczej i pod zmienionym nazwiskiem wychowuje się z dala od biologicznej matki i brata. Już jako dorosła kobieta przeprowadza się do Vancouver, by zamieszkać z mężem - kanadyjskim prawnikiem. Kiedy w 2008 r. dowiaduje się o tragedii w Syczuanie, przybywa do Chin, by zostać wolontariuszką. Oczywiście dochodzi także do trudnego i wzruszającego spotkania $\mathrm{z}$ rodziną.

W filmie pojawia się wątek, który w 2010 r. wciąż budził spore kontrowersje. Yuanni ma dwoje dzieci (są bliźniakami), a przecież w dniu premiery filmu obowiązywała jeszcze w Chinach zasada jednego dziecka. Ci, którzy mieli ich więcej, musieli liczyć się z wysokimi karami finansowymi, a także z faktem, że „nielegalne" potomstwo pozostawało często poza prawem. W wielu prowincjach nie można było nawet zarejestrować takich narodzin. Historycznie w filmie nie ma żadnego przekłamania, bowiem akcja rozpoczyna się w 1976 r., a więc jeszcze przed ogłoszeniem tej zasady, ustanowionej rok później i zniesionej dopiero w roku 2015. Niezależnie od tego wprowadzenie melodramatycznego wątku rozdzielonego rodzeństwa wydawało się posunięciem odważnym, choć w istocie było ono kolejnym elementem strategii przesuwania uwagi opinii publicznej $\mathrm{i}-\mathrm{w}$ gruncie rzeczy - fałszowania obrazu trzęsienia ziemi w Syczuanie.

Przywołane tu prace są oczywiście bardzo różnorodne, ale takie też było moje kryterium wyboru materiału do analizy. Chodziło mi o wskazanie wielości postaw (od krytycznych po apologetyczną) wobec silnie zideologizowanej narracji na temat trzęsienia ziemi w Syczuanie, które stało się nieoczekiwanym problemem dla chińskich władz - nie tylko z powodu ogromu zniszczeń, ale także dlatego, że zakłócało ono oficjalny przekaz dotyczący zmiany ustrojowej, jaka dokonywała się w Chinach na początku XXI w. Oczywiście światowa opinia publiczna nie przyjmowała go 
w sposób bezkrytyczny, ale wizerunek Chin musiał ulec zmianie. Odległy kraj za murem stał się - w dużej mierze za sprawą krytykowanej przez wiele osób olimpiady - bliższy, bardziej dostępny i na swój sposób przyjazny. Problem tylko w tym, że chińska zmiana ustrojowa obejmuje jedynie wybrane sfery i ma niewiele wspólnego z procesami rozgrywającymi się na przełomie lat 80. i 90. XX w. w Europie.

W filmie Fenga Xiaoganga trzęsienie ziemi zaskakuje Yuanni i jej męża podczas miłosnych igraszek na pace ciężarówki. Ta kolejna „odważna” scena oczywiście także jest częścią zideologizowanego przekazu filmu, ale - na bardziej podstawowym poziomie - podkreśla po prostu fakt, że kataklizm taki czy inny może zaskoczyć nas w najmniej spodziewanym momencie.

Pamiętam, jak w styczniu 2017 r. siedzieliśmy na tarasie domu w Orihuela Costa. Nie tyle poczuliśmy lekki wstrząs, ile zauważyliśmy, że kilka płytek ceramicznych nieoczekiwanie oderwało się od ściany. Nawet się nie potłukły i bez trudu przykleiłem je z powrotem. Wcześniej wspominano mi coś o obrazie spadającym ze ściany, o kilku potłuczonych kieliszkach... Miesiąc później mieliśmy już klucze do naszego hiszpańskiego domu w Torrevieja. Jego nazwa - po polsku ,stara wieża" - pochodzi od najstarszego lokalnego zabytku, mauretańskiej wieży z XIV w., będącej jedyną budowlą, jaka ocalała z trzęsienia ziemi w 1829 r. Miało ono siłę 6,6 stopnia w skali Richtera i doprowadziło do całkowitego zniszczenia kilku osad na terenie Costa Blanca. Na gruzach powstało miasto, gdzie nieoczekiwanie znaleźliśmy na starość nowy dom. Od niemal dwustu lat panuje tu względna cisza... Czasem tylko ziemia cichutko mruczy i choć wstrząsy nie przekraczają zwykle 1,5 stopnia, zawsze trafiają na pierwsze strony gazet.

Andrzej Pitrus

${ }^{1}$ Prawa autorskie do tego frywolnego określenia ma Alicja Helman. Używam za jej zgodą na licencji Creative Commons.

${ }^{2}$ Można o tym poczytać w: J. Boden, The Wall Behind China's Open Door: Towards Efficient Intercultural Management in China, ASP, Brussels 2008, s. 135 i n.

${ }^{3}$ Por. np. http://news.bbc.co.uk/2/hi/asia-pacific/7397489.stm (dostęp: 11.04.2019).

${ }^{4}$ Por. R. A. Kerr, R. Stone, A Human Trigger for the Great Quake of Sichuan?, „Science” 2009, t. 323, nr 5912, s. 322.

${ }^{5}$ S. Shiu-Hing Lo, The Politics of Crisis Management in China: The Sichuan Earthquake, Lexington Books, Lanham - Boulder - New York - London 2014.

${ }^{6}$ C. P. Sorace, Shaken Authority. China's Communist Party and the 2008 Sichuan Earthquake, Cornell University Press, Ithaca - London 2017.

${ }^{7}$ Por. The Great Tangshan Earthquake of 1976: An Anatomy of Disaster, red. Chen Yong, Tsoi
Kam-Ling, Chen Feibi, Gao Zhenhuan, Zou Qijia, Chen Zhangli, Pergamon Press, Oxford 1988, s. 153-154.

${ }^{8}$ A. H. Malcolm, Chinese Disclose That 1976 Quake Was Deadliest in Four Centuries, „New York Times", 2 czerwca 1977, s. 1.

${ }^{9}$ S. Kraicer, Shelly on Film: Tremors and Traumas. Notes on Three Chinese Earthquake Movies, http://dgeneratefilms.com/tag/wanglibo (dostęp: 11.04.2019).

${ }^{10}$ Por. https://web.archive.org/web/20100913053154/ http://www.cnngo.com/shanghai/play/aftershock-breaks-box-office-record-464710 (dostęp: 11.04.2019).

${ }^{11}$ The Oxford Handbook of Chinese Cinemas, red. C. Rojas, E. Chow, Oxford University Press, Oxford 2013, s. 232.

${ }^{12}$ Filmy tego rodzaju powstają też w innych krajach, np. w Korei czy Wietnamie. 